LEGISLATIVE AND OTHER MEASURES TAKEN BY GOVERNMENT TO REALISE THE RIGHT OF CHILDREN TO SHELTER ${ }^{1}$

ISSN 1727-3781

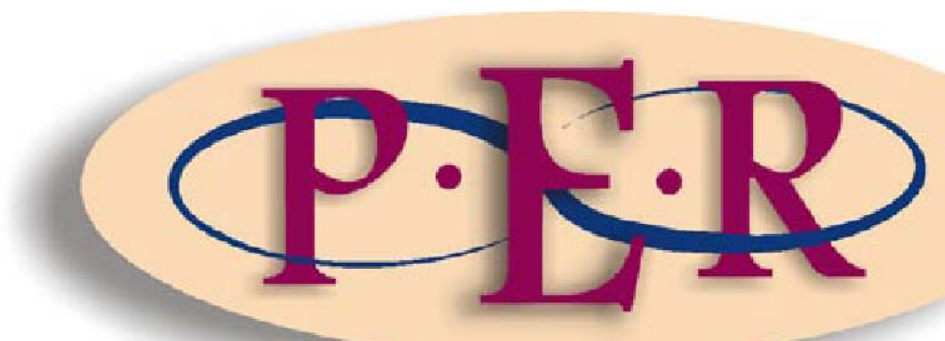

2004 VOLUME 7 No 1 


\section{LEGISLATIVE AND OTHER MEASURES TAKEN BY GOVERNMENT TO REALISE THE RIGHT OF CHILDREN TO SHELTER

\author{
I Mc Murray ${ }^{2}$ and L Jansen van Rensburg ${ }^{3}$ North-West \\ University (Potchefstroom Campus)
}

\section{Introduction}

The Constitution of the Republic of South Africa, $1996{ }^{4}$ entrenches numerous socio-economic rights. One of these socio-economic rights is contained in section 26 that grants everyone the right to have access to adequate housing and section 28 that grants every child the additional right to basic shelter among others.

In the Government of the Republic of South Africa and Others $v$ Grootboom and Others ${ }^{6}$ the court ruled that by virtue of section 28(1)(b) the primary responsibility to provide children with the necessary adequate housing/shelter is vested in their parents, unless the parents are unable to fulfil their duty or the children are removed from their care. This does not in the least mean that the state has no responsibilities to children living with their parents. The state must still provide the framework in which parents can facilitate the realisation of their children's rights. The state can fulfil this obligation by taking reasonable legislative and other measures within its available resources to realise everyone's right of access to adequate housing progressively. Therefore, the measures taken to realise section 26 also indirectly ensures the realisation of children's right to basic shelter (section 28(1)(c)).

All fundamental human rights are indivisible and interrelated. Clearly then, the state's obligations in terms of section 28(1)(c) cannot be properly interpreted without referring to the interpretation of those obligations conferred upon it by section 26(2) and the other socio

1 This article forms part of a National Research Foundation Project titled: "The utilisation of socioeconomic rights to alleviate the plight of poor children in South Africa." The financial assistance of the National Research Foundation: Social Sciences and Humanities towards this research is hereby acknowledged. Opinions expressed and conclusions arrived at are those of the authors and are not necessarily to be attributed to the National Research Foundation.

2 North-West University (Potchefstroom Campus).

3 North-West University (Potchefstroom Campus).

4 Constitution of the Republic of South Africa, 1996. Hereafter referred to as the Constitution.

5 For a detailed discussion on the right to shelter see Mc Murray and Jansen van Rensburg 2004 (1) PER $1-30$.

6 Government of the Republic of South Africa v Grootboom 200011 BCLR 1169 (CC) par [76]. Hereafter referred to as the Grootboom Constitutional Court case.

7 Grootboom Constitutional Court case par [78-79]. Also, see Minister of Health v Treatment Action Campaign 2002 10 BCLR 1033 (CC) par [77-78]. Hereafter referred to as TAC case. 
economic rights in the Constitution. Hence, section 28(1)(c) must be seen in the context of the Constitution as a whole. The state must therefore, take reasonable legislative and other measures within its available resources to realise children's right to basic housing/shelter progressively.

This article aims to examine the legislative and other measures taken by the state to realise the right to shelter of children. Firstly, the legislative measures taken specifically for the realisation of children's right to basic shelter as envisaged by section 28(1)(c) will be discussed. Thereafter attention will be drawn to those measures taken to ensure the progressive realisation of section 26.

\section{$2 \quad$ Legislative measures}

Section 26 provides everyone, including children, the right of access to adequate housing. Therefore, every measure taken to realise section 26 is indirectly applicable to the realisation of section 28(1)(c) and children's right to basic shelter.

\subsection{Legislation aimed at directly providing children with basic shelter}

Presently in South Africa, the Child Care Act of $1983^{8}$ is the primary legislative measure responsible for the safeguarding of children's interests. Most importantly, the Act provides the legal machinery designed to protect children who are considered for possible removal into alternative care as well as the fulfilment of the state's direct duty to provide children with the necessary care in instances where their parents are unable to do so.

It follows that children will be considered for removal from parental care, if the parents are unable to provide them with basic shelter. However, it has been submitted that this will only be a last resort taken if all else fails. To provide such children with the necessary shelter, the state may remove them into alternative care. In terms of the Act, alternative care can include places of safety, places of care, children's homes and foster care.

Places of safety are defined by section 1 of the Act as any place suitable for the reception of a child, into which the owner, occupier, or person in charge thereof is willing to receive the child. A court may remove a child into a place of safety if it appears that the child has no 
parent or guardian or if it is in the interest of or for the safety of the child to be placed in such alternative care. To facilitate the continued housing of children in places of safety, government has provided for the payment of a place of safety grant to the owner, occupier, or person in charge of such an establishment.

Secondly, the Act provides for the removal of children into places of care. A place of care is defined in section 1 as any building or premises maintained or used, whether for profit or otherwise, for the reception, protection, and temporary or partial care of more than six children. Places of care are sometimes referred to as a crèche or nursery school. These facilities provide care and shelter during those times the parents are unable to do so, without resorting to unnecessary permanent removal. ${ }^{11}$ There are also certain grants available to ensure the upkeep of these facilities.

Section 1 defines a children's home as any residence or home maintained for the reception, protection, care and bringing-up of more than six children apart from their parents. The purpose of children's homes is to ensure the permanent protection of children and to provide them with the necessary care such as housing. These institutions may include those belonging to churches, private bodies and organisations committed to the protection of children. ${ }^{13}$ Furthermore, to ensure compliance with their duty to protect and care for children, the state has also provided for grants for homes such as these.

Lastly, in this respect, the Act provides for children to be placed in foster care. Foster care is defined by the Act as care provided by any person except the guardian, in whose custody a child has been placed in terms of chapter 3 of the Act. ${ }^{15}$ Since 1996 child welfare agencies have reported an increase in the number of foster care applications. It was suggested that this reflected an increase in the number of orphaned children left homeless particularly because of AIDS. ${ }^{16}$ Once again, the state provides for foster parent grants to ensure that the children receive proper care. ${ }^{17}$ The foster care grants were intended to provide some monetary

9 S 11(1) of the Act. For a more detailed discussion, see Zaal 2001 SALJ 209.

10 Reg 39(1) of GN R2621 of 1986.

11 Bosman-Swanepoel and Wessels Child Care Act 16; see also Zaal 2001 SALJ 212.

12 Reg 38(1) of GN R2621 of 1986.

13 Bosman-Swanepoel and Wessels Child Care Act 11, see also Zaal 2001 SALJ 213.

14 Reg 37(1) of GN R2621 of 1986.

15 Ch 3 of the Child Care Act 1983 especially provides for the maintenance of children apart from their parents.

16 Clark 2000 SALJ 351-352. 17 Reg 36(1) of GN R2612 of 1986. 
assistance to foster parents who care for children while the state and private welfare organisations searched for a more permanent placement. However, because of the increase in care needing children, foster care has become more of a permanent solution rather than a temporary one as originally intended.

The Child Care Act of 1983 was last amended by the Child Care Amendment Act 86 of 1991, more than ten years ago. In the meantime, South Africa has become a democratic state in which children are afforded certain fundamentally entrenched rights. Furthermore, South Africa has become a signatory to the binding United Nations Convention on the Rights of the Child, which entails that its efforts to comply with this convention will be monitored by the Committee on the Rights of the Child. While considering South Africa's first report, this Committee expressed its concern about the insufficient number of alternative care facilities in previously disadvantaged communities. The Committee also recommended that the Child Support grants should be expanded and new alternative programmes be developed. $^{19}$ All these factors ${ }^{20}$ have necessitated the adoption of a new, more comprehensive piece of legislation to make provision for the changing face of children's rights. In answer to this need, the Minister of Social Development introduced the new Children's Bill on 12 August, $2003 .{ }^{21}$

The proposed Children's Bill is designed to give effect to the constitutional rights of children, as well as to give effect to the Republic's obligations concerning the well-being of children in terms of binding international instruments, particularly the UNCRC. ${ }^{22}$ The Bill is aimed at ensuring government's commitment to improving the quality of life of all citizens, especially children, and the alleviation of poverty amongst children in South Africa.

18 Hereafter referred to as the UNCRC.

19 Jansen van Rensburg and Olivier International and supra-national law 630.

20 In December 2002 the Law Commission of South Africa submitted a report concerning the 1983 Child Care Act. Due to the nature of this article a complete discussion of this report cannot be included. It is sufficed to say that the Law Commission's report concluded that the Child Care Act needs to be amended in various areas. See http://www.fclm.wits.ac.za for this report as well as a complete discussion concerning its findings and recommendations.

21 Children's Bill B70 of 2003 as reintroduced in the National Assembly as a section 75 Bill; explanatory summary of Bill published in GG 25346 of 13 August 2003. Hereafter referred to as the Bill.

22 This is clearly facilitated by ch 3 of the Bill, which reaffirms children's rights as stated in s 28 of the Constitution.

23 Clause 2 of the Bill reads: "The objects of this Act are - (a) to make provision for structures, services and means for promoting and monitoring the sound physical, intellectual, emotional and social development of children; (b) to strengthen and develop community structures which can assist in providing care and protection for children; (c) to protect children from maltreatment, abuse, neglect, degradation, discrimination, exploitation and any other physical and moral harm or hazards; (d) to provide care and protection to children who are in need of care and protection; (e) to give effect to the Republic's obligations concerning the well-being of children in terms of international instruments 
The Bill provides for the removal of children who are in need of care and protection, into alternative care. In terms of a child's right to basic shelter, clause 150(1) defines a child who is in need of care and protection as a child who -

(a) has been abandoned or orphaned or is without any visible means of support;

(b) displays behavior which cannot be controlled by the parent or care-giver;

(c) lives or works on the streets or begs for a living;

(d) is addicted to a dependence-producing substance and is without any support to obtain treatment for such dependency;

(e) has been exploited or lives in circumstances that expose the child to exploitation;

(f) lives in or is exposed to circumstances which may seriously harm that child's physical, mental or social well-being;

(g) may be at risk if returned to the custody of the parent, guardian or care-giver of the child as there is reason to believe that he or she will live in or be exposed to circumstances which may seriously harm the physical, mental or social well-being of the child;

(h) is in a state of physical or mental neglect; or

(i) is being maltreated, abused, deliberately neglected or degraded by a parent, a care-giver, a person who has parental responsibilities and rights or a family member of the child, or by a person under whose control the child is.

The provisions are largely similar to those in the Child Care Act of 1983, however, some development is evident along the lines of specific rights entrenched by section 28(1)(c).

\subsection{Legislation aimed at the realisation of section $26^{24}$}

Poverty is synonymous with lack of development and is a characteristic of underdevelopment. Development and the developmental process are, therefore, usually aimed at eradicating

binding on the Republic; and (f) generally, to promote the protection, development and well-being of children." 24 This section of the article will broadly focus on the legislative measures taken to implement s 26 of the Constitution. Also see Kollapen Annual Economic and Social Rights Report 33-45 of the South African Human Rights Commission (SAHRC: 2000-2002). 
poverty. ${ }^{25}$ Thus, the realisation of any socio-economic right necessarily implies an ongoing development process.

The Development Facilitation Act ${ }^{26}$ (DFA) introduced into our legal system development law principles for land development and measures to speed up the implementation of land development projects, especially the Reconstruction and Development Projects. In conjunction with the DFA, the National Development Agency Act ${ }^{27}$ established the National Development Agency. This agency is aimed at granting funds for project and programmes meeting the development needs of the poor communities.

Legislation more specifically applicable to the realisation of section 26 is now considered. The Housing Act ${ }^{28}$ provides for the facilitation of a sustainable housing development process in South Africa. This Act defines some key principles applicable to housing development by the national, provincial and local spheres of government. These principles include giving priority to the housing of the poor, wellmanaged housing development based on socio-economic realities, and creating safe and healthy housing conditions. The Less Formal Township Establishment Act provides for the designation, provision and development or establishment of townships for less formal forms of residential settlement. Furthermore, it regulates the use of land by tribes for communal forms of residential settlements. This Act also provides for instances where there is an urgent need for settlement in a less formal manner. People left homeless after a natural disaster or people who have been legally evicted by government serve as examples of an urgent need for less formal settlement. When people are in need of land for settlement on a permanent basis, the Provision of Land and Assistance Act ${ }^{31}$ can be utilised. In terms of this Act, the Minister of Land Affairs has the power and authority to make land and development funds available to people in need.

Because of the prevailing problem of homelessness and overpopulation in South Africa, many cases of unlawful occupation occur. The unlawful occupation of land can seriously frustrate the development process. The development process can also be seriously derailed when people are illegally evicted from land. The Prevention of Illegal Eviction from and Unlawful Occupation

\footnotetext{
25 Scheepers Law and Development 59.

26 Development Facilitation Act 67 of 1995. Hereafter referred to as the DFA.

27 National Development Agency Act 108 of 1998.

28 Housing Act 107 of 1997.

29 S 2 of the Housing Act 107 of 1997.

30 Less Formal Township Establishment Act 113 of 1991.

31 Provision of Land and Assistance Act 126 of 1993.
} 
of Land Act ${ }^{32}$ prohibits unlawful eviction and provides for the procedures to be followed when having to evict unlawful occupants. This Act also contains provisions to ensure that no one who has been evicted is left without the necessary shelter.

\section{Other measures}

There are several non-legislative measures taken to facilitate the direct and indirect realisation of children's socio-economic rights in order to alleviate poverty.

\subsection{National Programme of Action for Children in South Africa}

By ratifying the UNCRC, South Africa has committed itself to implementing the principle of a first call for children whereby the needs of children are considered paramount throughout the government's programmes, services and development strategies. The National Programme of Action for Children (NPA) is the instrument by which these commitments to children are being carried out. It is a mechanism for identifying all plans for children developed by government departments, non-governmental organisations and other child-related structures.

A National Steering Committee has been established to oversee the coordination, implementation, and monitoring of the NPA, as well as to ensure that it accords with the commitments to the UNCRC. Social welfare development as well as child protection measures are included in the Steering Committee's policy priorities. Within each of these policy areas, special attention will be paid to the needs of children living in difficult circumstances, or with special needs, such as children who are homeless, orphaned, or living in other forms of poverty. The implementation of the NPA will involve all departments and offices of government at all levels, as well as non-governmental organisations and all sectors of society. The process of applying the Convention's standards and principles will be built into the core of government and into all existing co-coordinating and policy development structures.

To summarise, the NPA will directly address the issue of children's housing rights, by implementing different programmes in order to alleviate the problem. Furthermore, the

32 Prevention of Illegal Eviction from and Unlawful Occupation of Land Act 19 of 1998.

33 This section will broadly discuss the main programmes and policies implemented to realise socio economic rights in South Africa. See Kollapen Annual Economic and Social Rights Report 23-33 (SAHRC: 2000-2002).

34 National Project on Poverty and Inequality 1998

http://www.loval.gov.za/DCD/ledsummary/led03c.html May 2003. 
National Steering Committee will ensure that every programme implemented to alleviate the childhousing crisis will comply with international standards set by the UNCRC. To be effective, the NPA must be implemented in close co-operation with all three spheres of government as well as other members of civil society and non-governmental organisations. On paper, this national action programme seems impressive. However, considering that government organisations are characterised by corruption and incompetence, the question need to be asked whether this programme will find proper implementation in practice?

\subsection{Reconstruction and Development Programme}

The Reconstruction and Development Programme (RDP) is a policy framework for integrated and coherent socio-economic progress. It seeks to mobilize South African and the country's resources toward the final eradication of the results of apartheid. Its goal is to build a democratic, non-racial, and nonsexist future and it represents a vision for the fundamental transformation of South Africa.

The RDP is based on the principle that socio-economic progress requires an integrated and sustainable programme, since the legacy of apartheid cannot be overcome with piecemeal, uncoordinated policies. Therefore, South Africa's recourses should be harnessed in a coherent set of strategies, which will be implemented in all three spheres of government. This has been confirmed on numerous occasions, most notably in the Grootboom case. ${ }^{36}$ Furthermore, the RDP acknowledges the fact that South Africa's people are the country's most important resource and to involve people in a democratic manner will promote peace and security.

The RDP base document refers to five key programmes as focus points. One of these programmes entails the meeting of basic needs. The basic needs of people extend from job creation and land reform to housing, social welfare and security. ${ }^{38}$ RDP projects are special projects that meet the basic needs and services of South Africa's people while building the economy and fundamentally transforming government and society. In relation to land, the RDP has implemented its Land Reform and Restitution Pilot Projects. The aim of these projects is to develop and support integrated sustainable rural development through land restitution,

35 White Paper on Reconstruction and Development 7.

Grootboom Constitutional Court case par [40, 47, 55].

White Paper on Reconstruction and Development 8-9.

38 Supra 9-12. 
redistribution, tenure reform, and settlement support. As confirmed by the National Programme of Action for Children, the principle of a first call for children was also adopted by the RDP. Therefore, the needs of children are also considered paramount and the UNCRC's standards and principles are featured centrally in all RDP programmes and projects. It then follows that the interest of children, especially those who are homeless and who live in other forms of extreme poverty will receive special attention in the RDP's integrated projects.

\subsection{Programmes and policies implemented by the National Department of Housing}

The National Department of Housing (NDH) implemented the following policies and programmes during April 2000 to March 2002 in order to facilitate the realisation of section

$26:^{40}$

- $\quad$ Amendment to the housing subsidy scheme;

- $\quad$ Environmentally Sound Low Cost Housing;

- $\quad$ Peoples Housing Process;

- $\quad$ Developer driven Individual subsidy Programme;

- $\quad$ Savings Linked Subsidy Scheme; and

- $\quad$ Programme for Housing Development in Emergency Circumstances.

The aim of the Amendment to the Housing Subsidy Scheme was to enable persons owning unsubsidised residential properties access to housing subsidies. According to the NDH, the main objective of the People's Housing Process as set out in the National Housing Code is to enable persons earning less than R3,500 per month to gain access to adequate housing. Persons who acquired ownership of residential property with their own resources are now also eligible for government subsidies.

The Developer Driven Individual Subsidy Programme targets small-scale developers who are unable to execute large subsidy projects. This programme provides for the deduction of funds based on the value of work completed, and does not require the use of a conveyancer to administer the subsidy funding.

39 Supra 51.

40 Kollapen Annual Economic and Social Rights Report 23 (SAHRC: 2000-2002).

41 Supra 24.

42 Supra 23-24.

43 Supra 25. 
Regarding the housing problem in South Africa, the Savings Linked Subsidy Scheme is partly aimed at providing and mobilising additional funding for low-income housing, while facilitating the development of a better standard of housing quality than is currently being delivered.

In light of the Grootboom case, the NDH is currently developing a housing development programme to address the emergency housing needs of affected persons such as children. ${ }^{45}$ The aim of this programme is to provide funding and development framework to undertake housing projects that would ensure that persons, including children who have no access to land, adequate housing and are living in deplorable conditions, receive some form of emergency shelter.

These national programmes and policies have also been implemented on provincial level by the Provincial Departments of Housing while taking their own province's specific needs into account.

\section{Government's role in implementing children's right to basic shelter and the alleviation of poverty}

Addressing poverty issues such as the need for adequate housing and shelter in South Africa will require that legislative and other measure be undertaken in a coherent manner across all three spheres of government, that is the national, provincial, and local spheres.

At national level government must establish and facilitate a sustainable housing development process by adopting national legislation, determining national policy, setting broad national housing delivery goals and budgetary goals. Furthermore, national government must provide assistance to the provinces and local government to ensure the effective compliance with their specific duties. Lastly, funding is allocated at national level for the facilitation of housing development in different housing programmes, such as those implemented in the RDP.

\footnotetext{
44 Supra 25.

45 Supra 25.

46 Supra $25-26$.

47 For a detailed discussion on the various policies and programmes implemented by the different Provincial Housing Departments, see Kollapen Annual Economic and Social Rights Report 27-33 (SAHRC: 2000-2002).

48 Scheepers Land and Development 54-55, see also Grootboom Constitutional Court case par [40, 55] for similar recommendations.
} 
In the provincial sphere, each province must do everything in its power to promote and facilitate the provision of adequate housing and shelter within the framework of the national housing policy. ${ }^{49}$ Because the housing problems and other forms of poverty differ from region to region, each province must determine its own policy, make laws, coordinate the housing delivery process and prepare a multi-year plan for financing purposes.

Local governmental authorities, being geographically on the spot, are well placed to respond to local trends in general poverty, and specifically to poverty caused by housing shortages that affect children. Therefore, each municipality must take the necessary steps to ensure that its inhabitants have access to adequate housing and emergency shelter. These steps must include local housing projects and housing delivery goals and local allocation of land and must generally promote effective housing development in their area.

The potential importance of the role of local government in the alleviation of child poverty was recognised in Schedule 4 of the Constitution. Schedule 4 is titled "Functional Areas of Concurrent National and Provincial Legislative Competence". Schedule 4B lists "child care facilities" as a "functional area of concurrent competence" involving expressly local government as well as the other two spheres of government. ${ }^{50}$ A logical interpretation would, therefore, be that childcare facilities such as children's homes and places of care represent an area of concurrent competence for local, provincial and national government. Because local government is situated at grassroots level, it can provide more effective compliance with this duty.

Alarmingly, the National Project on Poverty and Inequality, ${ }^{51}$ as well as the South African Human Rights Commission $^{52}$ found that municipalities are increasingly the site of a number of weaknesses, which could seriously undermine the progressive realisation of socio-economic rights and, therefore, hinder the alleviation of poverty in that area. In several instances attention was drawn to severe weaknesses in the capacity of local governments to function as development facilitators. Reference was also made to structural constraints on their operations,

49 Scheepers Land and Development 55. See also Grootboom Constitutional Court case par [47, 55] for similar recommendations. 50 Zaal 2002 SALJ 138-145.

51 National Project on Poverty and Inequality 1998 http://www.loval.gov.za/DCD/ledsummary/led03c.html May 2003.

52 Kollapen Annual Economic and Social Rights Report 54 (SAHRC: 2000-2002). 
and in particular, to resource constraints. To ensure successful poverty alleviation, these grassroots problems must be dealt with.

The White Paper on Local Government ${ }^{54}$ introduced the Integrated Development Planning (IDP) ${ }^{55}$ as one of the most important methods of achieving greater coordination and integration in development planning. Local government has been given a Constitutional mandate ${ }^{56}$ to create and sustain humane, equitable and viable human settlements. It is however, doubtful whether Local Government, as presently designed, is adequately equipped to fulfill this developmental mandate in order to alleviate and eradicate poverty. Local government has been democratized, but the Local Government System is still structured to meet the demands of the previous era. Therefore fundamental transformation of Local Government is required to accommodate the human rights elements entrenched in the Bill of Rights. Integrated Development Plans provide powerful tools for local municipalities to facilitate integrated and coordinated planning as well as effective service delivery for the short, medium, and long term. Integrated Development Planning is regarded as a principle tool for bridging the gap between the current development reality and the vision of accountable and sustainable development and service delivery. All municipalities in South Africa have embarked on integrated planning processes. Integrated Development Planning will enable municipalities to develop strategic policy capacity, to mobilise resources and to target their activities.

53 Supra 54-55.

54 White Paper on Local Government issued by the Minister of Provincial Affairs and Constitutional Development in March 1998. Herein after referred to as the Local Government White Paper.

55 It is compulsory for every municipality to have an IDP. See ch 5 of the Municipal Systems Act 32 of 2000.

56 S 152(1) and 152(a) of the Constitution. S 152(1) states that the objects of local government are "(a) to provide democratic and accountable government for local communities; (b) to ensure the provision of services to communities in a sustainable manner; (c) to promote social and economic development; (d) to promote a safe and healthy environment; and (e) to encourage the involvement of communities and community organisations in the matters of local government". S 153(a) further states that "a municipality must structure and manage its administration, budgeting, and planning processes, to give priority to the basic needs of the community, and to promote the social and economic development of the community". See s 23(1) of the Municipal Systems Act 32 of 2000. S 23(1) reads "a municipality must undertake developmentally-oriented planning so as to ensure that it (a) strives to achieve the objects of local government set out in section 152 of the Constitution; (b) gives effect to its developmental duties as required by section 153 of the Constitution; and (c) together with other organs of state contribute to the progressive realisation of the fundamental rights contained in sections 4, 25, 26, 27 and 29 of the Constitution". (Own emphasis.)

57 Scheepers Land and Development 237. See also s 26 of the Municipal Systems Act 32 of 2000. 
The IDPs will normally include the DFA principles ${ }^{58}$ that serve as guidelines according to which municipalities can build sustainable and liveable settlements in their area. Once again, it must be stressed that building sustainable and liveable settlements takes more than bricks and mortar, and depends on integrated service delivery, regulation, and planning of all aspects of land use, health, infrastructure, environmental management and transport. The IDP should help to align scarce resources behind the agreed upon policy objectives and programs and insure that actions are prioritised against urgent needs. A strategic approach will enable municipalities to use what resources are available to do so as much as possible of what is critical.

\section{$5 \quad$ Conclusion}

Most of the discussed legislative and other measures are aimed at realising everyone's right of access to adequate housing, this includes children. However, most of these measures make little mention of the specific right of children to basic shelter. It is regarded as inclusive in the overall application of the legislation. Once again, it must be stressed that these legislative and other measures, in order to comply with the standard of reasonableness, must regard the interest of children to be paramount. If such legislation does not provide for the interest of children as a vulnerable group, it can be argued that the relevant legislative measure is not constitutionally valid.

It is submitted that national government must recognise the importance of the role of local government, and local government should increasingly assume policy-making and implementation powers in their area. This will go a long way to building local capacity to function as effective development facilitators. As far as the resource problem is concerned, corruption in municipalities should be eradicated, while municipal capacity to manage and mobilise resources must be enhanced.

The importance of co-operative government cannot be over emphasised. Without an effective integrated plan of action, which includes cooperation between all three spheres of government, as well as the participation of civil society, especially people who are directly affected by the

58 This refers to the Development Facilitation Act 67 of 1995 and its principles. According to s 26(d) of the Municipal Systems Act 32 of 2000 the council's development strategies must be aligned with any national or provincial sectoral plans and planning requirements binding on the municipality in terms of legislation. 
implementation of socio-economic rights, realising the right of children to shelter will only exist on paper. 


\section{Bibliography}

Bosman-Swanepoel and Wessels Child Care Act Bosman-Swanepoel HM and Wessels PJ A Practical approach to the Child Care Act (Digma Pretoria 1995)

Clark 2000 SALJ Clark B "The duty of the state to support children in need" 2000 SALJ 351-352

Jansen van Rensburg and Olivier International and supra-national law Jansen van Rensburg L and Olivier MP "International and supra-national law" in Olivier MP, Smit N and Kalula ER (eds) Social Security a Legal Analysis (Butterworths Durban 2003)

Kollapen Annual Economic and Social Rights Report Kollapen J 4th Annual Economic and Social Rights Report of the South African Human Rights Commission (2000-2002) (SAHRC Johannesburg 2003)

Mc Murray and Jansen van Rensburg 2004 (1) PER 1-30 Mc Murray I and Jansen van Rensburg L "The utilisation of the right of children to shelter to alleviate poverty in South Africa" 2004 (1) PER 1-30

Scheepers Law and Development Scheepers T A Practical Guide to Law and Development (Juta Kenwyn 2000)

Zaal 2002 SALJ Zaal N "Local government and the provision of child care services: an essential area for legislative reform" 2002 SALJ 138-145

Zaal 2001 SALJ Zaal N "Casting children out into a legal wilderness? A critical evaluation of the definitions care facilities in the Child Care Act 74 of 1983" 2001 SALJ 209

\section{Register of acts, bills, whitepapers and government notices}

Child Care Act 74 of 1983 Child Care Amendment Act 86 of 1991 Children's Bill B70 of 2003 Constitution of the Republic of South Africa 1996 Development Facilitation Act 67 of 1995 GG 25346 of 13 August 2003 GN R2612 GG 10546 of 12 December 1986 Housing Act 107 of 1997 Less Formal Township Establishment Act 113 of 1991 Municipal Systems Act 32 of 2000 National Development Agency Act 108 of 1998 Prevention of Illegal Eviction from and Unlawful Occupation of Land Act 19 of 1998 Provision of Land and Assistance Act 126 of 1993 White Paper on Local Government White Paper on Reconstruction and Development 


\section{Register of cases}

Government of the Republic of South Africa and Others v Grootboom and Others 200011 BCLR 1169 (CC)

Minister of Health and Others v Treatment Action Campaign and Others 200210 BCLR 1033 (CC)

\section{Register of internet references}

National Project on Poverty and Inequality 1998 [Found on the Internet] HYPERLINK http://www.loval.gov.za/DCD/ledsummary/led03c.html [Date of use 20 May 2003]

South African Law Commission 2002 Review Of The Child Care Act Project 110 [Found on the Internet] HYPERLINK http://www.law.wits.ac.za/salc/report/report.html or http://www.fclm.wits.ac.za [Date of use 20 May 2003] 